\title{
The Main Approaches of Studying the Mechanisms of Action of Artificial Electromagnetic Fields on Cell
}

Yuriy Shckorbatov*

Institute of Biology, Kharkiv National University, Ukraine

\begin{abstract}
The effects of Electromagnetic Fields (EMFs) on health are discussed. These effects produce public interest to biological action of EMFs. The cell effects of EMFs have to be investigated to understand the mechanism of the biological action of EMFs. Among such mechanisms three main points are discussed: EMF action on cell membranes; EMF action on free radical concentration in cell; the action of EMF on intracellular regulatory systems. The analysis of experimental results proves the multilateral nature of the impact of EMFs on cell.
\end{abstract}

Keywords: Cell; Cell nucleus; Cell membrane; Microwaves; Magnetic field

\section{Introduction}

The problem of the influence of Electromagnetic Fields (EMFs) on biological objects has a long history. Now this problem attracts keen public interest in connection to increase of "electromagnetic pollution" of environment. In this century by Banik S, Bandyopadhyay S, Ganguly S; Vorst AV, Rosen A, Kotsuka Y; Barnes FS, Greenebaum B; Furse C, Christensen DA, Durney $\mathrm{CH}$ are reviewed the main facts of EMFs effects on cells [1-4]. The medical applications of EMFs are reviewed by Rosch PJ, Markov MS; Andrä W, Nowak H; Markov MS [5-7]. Some of theoretical models proposed to explain the basic phenomena associated with cell exposure to EMF are presented in review articles [8-21].

Now some new data are emerging and the approaches to the problem of the action of electromagnetic factors on cells are changing in accordance to the new developments in biology as a whole. I would like to present the brief description of the main directions of research in this field.

The most important, in our opinion, are three primary biological mechanisms of action of EMFs on cell. First, the action on cell membranes, second, the action on free radical concentration in cell, and the third, the action of EMF on intracellular regulatory systems. The known effects of EMFs on numerous isolated enzyme reactions may acquire the biological meaning in their connection to the mentioned above mechanisms.

Traditionally, the biological effects of EMFs are divided in two groups: "thermal" and "non-thermal". For microwave radiation the EMF irradiation with the level of surface power density less than 10 $\mathrm{mW} / \mathrm{cm}^{2}$ is assumed as not inducing the significant thermal effects in the biological objects and the effects of microwaves with surface power density more than $10 \mathrm{~mW} / \mathrm{cm}^{2}$ as "thermal" [22]. This classification is provisional, but it enables to separate the effects of EMFs related mainly with heating of biological tissue. In this work we will discuss non-thermal effects of EMFs. First, in order to show the importance of the issues discussed for humans we consider some of the effects of electromagnetic fields on human organism.

\section{Effects of Exposure to Anthropogenic EMFs on Human Health}

The environmental and health effects of electromagnetic radiation produced by mobile phones, mobile phone base stations, TV transmitting towers, and some medical equipment induce public concern. Some investigations analyzing the health effects of the electromagnetic radiation produced by these sources of electromagnetic radiation are observed below.

Electromagnetic fields of Radiofrequency (RF) range cover wide spectrum of frequencies. The ionosphere very effectively shields the earth's biosphere from radiations of this type originating in space. Electromagnetic fields and radiation of high intensity may be generated by natural electrical phenomena such as those accompanying thunderstorms. However, in the frequency range of $100 \mathrm{kHz}$ to $300 \mathrm{GHz}$, the intensity of natural fields and radiation is low. Exposure of the urban population in the USA to man-made microwave sources was found by Janes (1979) to vary from a very low value to as high as $100 \mu \mathrm{W} / \mathrm{cm}^{2}$. The median exposure to the total microwave flux from external sources for this population was calculated to be $0.005 \mu \mathrm{W} / \mathrm{cm}^{2}$. Although concern about microwave and RF effects and possible hazards arose first in highly developed countries, the problem is universal [23].

The mobile telephony is widespread in the modern world. The data about the usage of mobile telephony are presented in review [24]: "In 2010, cell phone subscribers in the U.S. numbered 287 million, Russia 220 million, Germany 111 million, Italy 87 million, Great Britain 81 million, France 62 million, and Spain 57 million". The "microwave sickness syndrome" among people working with microwaves was first described in Soviet and Polish medicine, this syndrome includes fatigue, dermographism, headaches, insomnia, changes in blood pressure, tumors, impotence, skin symptoms and memory impairment, among others. The skepticism about this syndrome was expressed in the West, but now is admitted the possible neurological basis for this syndrome $[24,25]$. It was proved that there was a significant relation of some symptoms to measured EMF power density; this was highest for headaches. Authors express their opinion that despite very low exposure

*Corresponding author: Yuriy Shckorbatov, Institute of Biology, Kharkiv National University, pl. Svobody, 4, Kharkiv, 61077, Ukraine, Tel: 380577075262; E-mail: yuriy.shckorbatov@gmail.com

Received January 07, 2014; Accepted March 05, 2014; Published March 07, 2014

Citation: Shckorbatov Y (2014) The Main Approaches of Studying the Mechanisms of Action of Artificial Electromagnetic Fields on Cell. J Electr Electron Syst 3: 123 doi:10.4172/2332-0796.1000123

Copyright: $\odot 2014$ Shckorbatov $Y$. This is an open-access article distributed under the terms of the Creative Commons Attribution License, which permits unrestricted use, distribution, and reproduction in any medium, provided the original author and source are credited. 
to HF-EMF, effects on wellbeing and performance cannot be ruled out, however, mechanisms of action at low EMF levels are unknown [26].

In many investigations the frequency of micronuclei and chromosomal aberrations tests which indicate the level of genetic damage (genotoxic effects) are used. Micronuclei are emerging in cells after action of different factors (mutagenic factors) which influence the process of cell division or the process of origin of mutations. Chromosome aberrations are the impairments in chromosome structure visible in light microscope. The results of one of such investigations show that there was no significant difference of micronucleus frequency and chromosomal aberrations in human blood cells between the groups of people living around mobile phone base stations and control group [27].

Some investigations indicate an increased risk for cancer - acoustic neuroma and glioma after $>10$ years of mobile phone usage. Authors conclude that current standard for exposure to microwaves during mobile phone use is not safe for long-term exposure and needs to be revised $[16,28]$. But the increased cancer risk among mobile telephone users is not detected by some investigators. It was observed no increased risk for basal cell carcinoma, squamous cell carcinoma, or melanoma of the head and neck, little evidence of an increased skin cancer risk was observed among mobile phone users after at least 13 years of mobile telephone usage [29].

The association between childhood acute lymphoblastic leukemia and power lines was revealed. This study emphasizes on risk of acute lymphoblastic leukemia following living close to overhead high voltage power lines. Authors propose consider legal limitation for building constructions in at least 600 meters from high voltage power lines [30].

To investigate the risk of early childhood cancers associated with the mother's exposure to radiofrequency radiation from mobile phone base stations (masts) during pregnancy. It was demonstrated that is no association between the risk of early childhood cancers and mother's exposure to mobile phone base stations during pregnancy [31].

The epidemiological evidence suggests an association between occupational exposure to ELF-EMF and Alzheimer disease. However, some limitations affecting the results from this meta-analysis should be considered [32].

The possible health hazardous effects of magnetic resonance imaging (MRI) were also explored. While the whole data does not confirm a risk hypothesis, it suggests a need for further studies and prudent use in order to avoid unnecessary examinations, according to the precautionary principle [33]. In 2003, the FDA declared nonsignificant risk status for MRI clinical systems generating static fields up to $8 \mathrm{~T}[34]$.

In spite of existing of some investigations indicating the negative health impact of EMF the general estimation of the EMF-induced health hazard was optimistic. The International Commission on Non-Ionizing Radiation Protection makes such conclusion based on the analysis of many epidemiologic investigations. Results of epidemiological studies to date give no consistent or convincing evidence of a causal relation between RF exposure and any adverse health effect. On the other hand, these studies have too many deficiencies to rule out an association. In the last few years the epidemiologic evidence on mobile phone use and risk of brain and other tumors of the head has grown considerably. In opinion of members of International Commission on Non-Ionizing Radiation Protection, overall the studies published to date do not demonstrate a raised risk within approximately ten years of use for any tumor of the brain or any other head tumor [35]. Nevertheless, the WHO International Agency for Research on Cancer (IARC) evaluated the extremely low frequency magnetic fields as possibly carcinogenic to humans (Group 2B). Static magnetic fields and static and extremely low frequency electric fields could not be classified as to carcinogenicity to humans [36]. IARC has classified radiofrequency electromagnetic fields as possibly carcinogenic to humans (Group $2 \mathrm{~B}$ ), based on an increased risk for glioma, a malignant type of brain cancer, which is associated with wireless phone use [37].

The problem of adequate assessment of EMF influence on human organism is very important. We believe that the state of individual cell in our organism is directly linked to the state of the whole organism. Stress-related changes in the cell nucleus are generally associated with transitions of main cell nucleus component chromatin from the diffused state euchromatin to more condensed state - heterochromatin. We propose to use euchromatin $\rightarrow$ heterochromatin transitions in cells of human buccal epithelium (cells from the surface of the cheek's mucosa) to assess the EMF-induced effects. As a criterion for determination of changes in the state of human buccal epithelium cell under the EMF action we proposed the Heterochromatin Granule Quantity (HGQ) in the cell nucleus [38].

\section{EMF Action on Cell Membranes}

The interest of investigators to EMFs effects on the cell membranes was stimulated by the theoretical work [39]. The author drives a conclusion very interesting to biologists. It should be remembered that cells have a membrane of about $10^{-6} \mathrm{~cm}$ thickness which maintains a very strong dipolar layer. In the (from the point of view of physics) complicated shape of a cell surface, local vibrations of a part of the cell membrane are feasible such that the positive and the negative part of a particular section of the membrane vibrate against each other leading to an oscillating electric dipole. Its frequency is of the order $10^{11}-10^{12} \mathrm{sec}^{-1}$ if a sound velocity in the layer of order $10^{5}-10^{6} \mathrm{~cm} / \mathrm{sec}$ perpendicular to the surface is assumed [39]. Indeed in many experimental works the effects of microwaves upon biological membranes were observed. The increase of cell membrane permeability to sodium and potassium ions was demonstrated [40-42]. Interestingly, that the microwave-induced increase of permeability to sodium ions was found to be reversible and returns to normal level within $60 \mathrm{~min} \mathrm{[42].} \mathrm{As} \mathrm{it} \mathrm{was} \mathrm{supposed} \mathrm{that}$ the increase of permeability to ions is due to "micro-thermal" effects in cell membranes induced by microwaves [40]. Now the corresponding calculations of EMF-induced thermal gradients in membranes are done. The calculation on the impact of electric field induced thermal gradients across the plasma membrane may be applied to either Pulsed Electric Fields (PEFs) or Alternating Current (AC) fields [43]. The socalled "resonance" effects of microwaves on membrane permeability, i.e. the effect may be induced by EMF of the strictly determined wavelength and not induced at near frequencies, also were discussed [44]. It was demonstrated that in cells of algae Nitellopsis obtusa exposed to microwaves at frequencies of microwaves of 49,70 and 76 $\mathrm{GHz}$ the chloride transmembrane current increased by $200-400 \%$, at frequencies of 41.5 but at $71 \mathrm{GHz}$ it decreased [45].

The microwave-induced effects (frequency of 37,5; 18,75 and 36.64 $\mathrm{GHz}$ ) of increase of permeability of cell membranes to cytological stains (vital dyes) in living human buccal epithelium cells were reported $[46,47]$. Interestingly, that microwave-induced change in permeability to vital dye may recover in 2 hour period [47].

The effects of exposure to a $50 \mathrm{~Hz}$ magnetic field (maximum of 41.7 to $43.6 \mathrm{mT}$ ) on the membrane protein structures of living HeLa cells 
were studied using attenuated total reflection infrared spectroscopy. One min of such exposure shifted peak absorbance of the amide I band to a smaller wave number, reduced peak absorbance of the amide II band, and increased absorbance at around $1600 \mathrm{~cm}^{-1}$. These results suggest that exposure to the ELF magnetic field has reversible effects on the peptide linkages, and changes the secondary structures of cell membrane proteins [48].

The experiments were also held in model membranes [49]. The suspension of egg lecithin multilamellar vesicles (liposomes) was exposed to $900 \mathrm{MHz}$ microwave radiation for $5 \mathrm{~h}$. Specific Absorption Rate (SAR) of the radiation for the investigated liposome sample was 12 $\pm 1 \mathrm{~W} / \mathrm{kg}$. Liposomal changes were monitored using a light scattering technique. Optical anisotropy of the liposome sample decreased dramatically upon exposure to microwave radiation, indicating structural changes in acyl chain packing. Infrared (IR) and Nuclear Magnetic Resonance ( ${ }^{(1)} \mathrm{H}$ NMR) studies showed an increased damage upon exposure to microwaves. The changes observed in the ${ }^{(1)} \mathrm{H}$ NMR spectrum of the microwave exposed sample indicated hydrolysis of carboxylic and phosphoric esters. IR study showed conformational changes in the acyl chains of the lipids upon microwave exposure. However, both IR and ${ }^{(31)} \mathrm{P}$ NMR did not show any appreciable changes in the head group part of the lipids [49].

A critical evaluation of three theories that describes the effects of weak electromagnetic fields on channel proteins in the cell membrane was done [50].

\section{EMF Action on Free Radical Concentration in Cell}

A free radical is a molecule or atom that has unpaired valence electrons. Free radicals are formed in cells and are involved in many intracellular processes. These compounds are capable to react with the cell structures causing their deterioration, so their excess is unfavourable. In particular, the free radical excess induces mutations and apoptosis the programmed cell death. The "radical pair mechanism" is proposed to explain the phenomenon of "compass" in birds [51,52].

The role of Static Magnetic Field (SMF) in production of free radicals in cell is discussed in the review [11]. Authors propose that the primary cause of changes in cells after incubation in external SMF is disruption of free radical metabolism and elevation of their concentration. Such disruption causes oxidative stress and, as a result, damages ion channels, leading to changes in cell morphology and expression of different genes and proteins and also changes in apoptosis and proliferation [11]. The review of microwave effects on free radical formation in connection to male reproductive system one can find in [13]. Many investigations are analysing the microwave-induced effects on free radical concentration in cell, the problem of so-called oxidative stress. This problem attracts public concern in connection with interest to possible hazards of using mobile telephones. The aspects of the problem of EMF-induced free radicals in connection with neurodegenerative diseases are reviewed in review [53]. Some of experimental investigations studying the microwave-induced changes in the free radical situation in the cell are presented below.

Rats were exposed to $900 \mathrm{MHz}$ EMF for 7 days ( $1 \mathrm{~h} /$ day). In other experimental groups, rats were exposed to EMF and pretreated with of Ginkgo biloba extract (Gb). Subsequently, oxidative stress markers and pathological changes in brain tissue were examined for each group. Oxidative damage was registered in the experimental group but these alterations were prevented by Gb treatment. Furthermore, Gb prevented the EMF-induced cellular injury in brain tissue which was demonstrated by histopathology methods [54].
The exposure of rats to electromagnetic radiation produced by GSM mobile phone induced in plasma a significant decrease in enzymes that defend cell from the elevation of free radical level: Catalase (CAT) and Superoxide Dismutase (SOD). The effect of acute doses of EMF on the rat's antioxidant status is significantly higher than that of fractionated doses of the same type of radiation [55].

In experiment on male guinea pigs exposed from $890-$ to $915-\mathrm{MHz}$ EMF $(217-\mathrm{Hz}$ pulse rate, $2-\mathrm{W}$ maximum peak power, SAR $0.95 \mathrm{w} / \mathrm{kg}$ ) of a cellular phone for $12 \mathrm{~h}$ /day (11-h 45-min stand-by and 15-min spiking mode) for 30 days the changes in free radical marker malonic aldehyde (MDA) and antioxidant substances were shown. It was found that the MDA level increased $(\mathrm{P}<0.05)$, glutathione level and CAT enzyme activity decreased $(\mathrm{P}<0.05)$, and vitamins $\mathrm{A}, \mathrm{E}$ and $\mathrm{D}(3)$ levels did not change $(\mathrm{P}>0.05)$ in the brain tissues of EMF-exposed guinea pigs. It was concluded that electromagnetic field emitted from cellular phone might produce oxidative stress in brain tissue of guinea pigs [56].

In experiments on Wistar female rats exposed to PC irradiation of monitor of Cathode Ray Tube (CRT) type the changes in eye corneal and lens tissues were investigated. In corneal tissue, MDA levels and CAT activity were found to increase in the computer group compared with the control group. Regarding lens tissue, MDA levels SOD activity and glutathione peroxidase activity (GSH-Px - the enzyme protecting cell from oxidative damage) were found to increase, as compared to the control group. The authors suppose that results of this study suggest that computer monitor radiation leads to oxidative stress in the corneal and lens tissues, and that vitamin $\mathrm{C}$ may prevent oxidative effects in the lens [57].

If the human Peripheral Blood Mononuclear Cells (PBMC) were exposed to the EMF of $900 \mathrm{MHz}$ radiofrequency at a Specific Absorption Rate (SAR) of $\sim 0.4 \mathrm{~W} / \mathrm{kg}$ longer than two hours, the apoptosis (the programmed cell death) is induced. The authors suppose that the activation of free radicals - Reactive Oxygen Species (ROS) is triggered by the conformation disturbance of lipids, protein, and DNA induced by the cell exposure [58].

In experiments with Wister rats located in the vicinity of the base station, estimated distance was less than $10 \mathrm{~m}$ the changes in free radical concentration were investigated. The frequency of radiation was 1800 $\mathrm{MHz}$, SAR $0.95-2 \mathrm{~W} / \mathrm{kg}$ for 40 and/or 60 days continuously. The study demonstrates slight decrease in the activity of glutathione reductase, lipid peroxidation as measured by MDA and total cholesterol in all tissues investigated when rats were exposed to radiation emitted from base station in 40 days. These parameters decreased when the period of exposure was extended to 60 days [59].

In experiments with the primary cultured cortical neurons exposed to pulsed electromagnetic fields at a frequency of $1800 \mathrm{MHz}$ modulated by $217 \mathrm{~Hz}$ at an average SAR of $2 \mathrm{~W} / \mathrm{kg}$ the oxidative damage was demonstrated [60]. At $24 \mathrm{~h}$ after exposure the radiation induced a significant increase in the levels of 8-hydroxyguanine (8-OHdG), a common biomarker of DNA oxidative damage, in the mitochondria of neurons. Concomitant with this finding, the copy number of mitochondrial DNA (mtDNA) and the levels of mitochondrial RNA (mtRNA) transcripts showed an obvious reduction after RF exposure. Each of these mtDNA disturbances could be reversed by pretreatment with melatonin, which is known to be an efficient antioxidant in the brain. Together, these results suggested that $1800 \mathrm{MHz}$ RF radiation could cause oxidative damage in mtDNA in primary cultured neurons. In authors' opinion the oxidative damage of mtDNA may account for the neurotoxicity of RF radiation in the brain [60]. 
The investigation of EMF of mobile telephone on oxidation situation in rat sperm was done [61]. The frequency of the cell phone was 900 $\mathrm{MHz}$, pulse GSM mode. The specific absorption rate was estimated to be $0.9 \mathrm{~W} / \mathrm{kg}$. The MDA concentration, SOD, CAT, and GPx activity were determined in sperm samples. The result shows a significant MDA increase in the mobile phone-exposed group as compared with the control ones. The reduction in GPx and SOD activity and an increase in CAT activity were observed after animal exposure to microwaves. Authors conclude that overproduction of reactive oxygen species (ROS) under microwave field exposure. Authors propose hypothetical scheme of action of EMF on enzyme histone kinase activity, micronuclei, cell cycle, and antioxidant enzymes via increase of intracellular concentration of free radicals as a primary mechanism [61].

In male Fischer-344 rats exposed to $900 \mathrm{MHz}$ microwave radiation $\left(\mathrm{SAR}=5.9 \times 10^{-4} \mathrm{~W} / \mathrm{kg}\right)$ and $1800 \mathrm{MHz}$ microwave radiation $(\mathrm{SAR}=$ $\left.5.8 \times 10^{-4} \mathrm{~W} / \mathrm{kg}\right)$ for 30 days $(2 \mathrm{~h} /$ day $)$ the significant impairment in cognitive function and induction of oxidative stress in brain tissues was registered [62,63].

As one can see, the microwave irradiation produces the oxidation stress in different tissues of laboratory animals and antioxidants added to animal nutrition may to definite extent prevent such consequences of microwave exposure. As antioxidants were used the extract of Gínkgo biloba [54], vitamin E and vitamin A [55], vitamins A, E and D [56], vitamin C [57], and even garlic [64].

The low-energy EMFs of Extremely Low Frequency (ELF) also induce the oxidative stress [65-68], but such effect is not always registered $[69,70]$. The prolongation of ELF exposure can result in adaptation to this factor [70].

It was supposed that the cell membranes may be the target of ROS [71] so the membrane permeabilization may be induced by the EMFresulted ROS overproduction. At the same time the highly significant relationships was established between SAR, the oxidative DNA damage bio-marker, 8-OH-dG, and DNA fragmentation after microwave (1.8 GHz SAR from $0.4 \mathrm{~W} / \mathrm{kg}$ to $27.5 \mathrm{~W} / \mathrm{kg}$ ) exposure of human spermatozoa [72]. About the analogous oxidative damage induced by EMF in rats mitochondrial DNA it was mentioned above [60]. So, the oxidative stress produced by EMFs may be the cause different negative consequences of EMF - micronuclei formation [61,73-75] and DNA strand breaks [76-78].

\section{The Action of EMF on Intracellular Regulatory Systems}

The fact that EMFs may regulate gene expression was demonstrated in many experimental works. Mainly the interest of researchers is concentrated on genes coding the proteins connected with the process of regulation of gene activity, for instance, the proteins c-jun, c-myc; or proteins connected with stress reaction of cells, first of all so-called heat shock proteins, for instance, hsp-70; or very important regulatory proteins $\mathrm{p} 53$ and $\mathrm{p} 21$. There are evidences of microwave exposure (1,71 $\mathrm{GHz}$ ) influence on hsp70, c-jun, c-myc, and p21 levels in p53-deficient cells, but not in wild-type cells [79]. The EMF-induced changes of the transcript level of cell cycle regulatory and apoptosis-related genes were shown $[80,81]$. The 3.5 fold upregulation of mRNA stress-related transcription factor bZIP after exposure to $900 \mathrm{MHz}$ microwaves was shown [82]. After the exposure of human lens epithelial cells to 1800-MHz GSM-like radiation for $2 \mathrm{~h}(\mathrm{SAR}-1.0,-3.5 \mathrm{~W} / \mathrm{kg})$ four proteins were upregulated. The heat-shock protein 70 (HSP70) and heterogeneous nuclear ribonucleoprotein $\mathrm{K}$ (hnRNP K) were among upregulated proteins [83]. The proteomic analysis revealed fourteen proteins specifically up-regulated by EMF (GSM 1800, $2 \mathrm{~W} / \mathrm{kg}$ ) in
Jurkat cells. The examples of proteins specifically up-regulated by EMF are: heat shock protein 70 , ubiquitin carboxyl-terminal hydrolase 14 and $26 \mathrm{~S}$ protease regulatory subunit $6 \mathrm{~B}$ [83]. Evidences of EMFinduced changes in transcriptiome (all transcripts synthesized by one cell or group of cells, including mRNA and non-coding RNA) and proteome (all proteins synthesized by one cell or group of cells) one may find in [84-86].

The EMF-induced changes in transcriptome and proteome are not registered in several studies. For instance, to seek alterations in gene transcription in bone marrow cells following in vivo exposure of juvenile mice to power frequency magnetic fields, young (21-24-day old) $\mathrm{C} 57 \mathrm{BL} / 6$ mice were exposed to a $100 \mu \mathrm{T} 50 \mathrm{~Hz}$ magnetic field for $2 \mathrm{~h}$. A pilot experiment with 6 exposed (E) and 6 non-exposed (NE) mice identified four candidate responsive transcripts (two unknown transcripts (AK152075 and F10-NED), phosphatidylinositol binding clathrin assembly protein (Picalm) and exportin 7 (Xpo7)). A larger experiment compared $19 \mathrm{E}$ and $15 \mathrm{NE}$ mice using two independent QRT-PCR assays and repeated microarray assays. No significant fielddependent changes were seen, although Picalm showed a trend to significance in one QRT-PCR assay [87].

The experiments in which the EMF-treated cells not revealed the specific changes in transcription or proteome changes are described in [88-96]. The differences in results in genomic and proteomic experiments with EMF-treated cells may be connected with methodological problems [97]. In our opinion the existence of results not revealing the EMF-induced changes in transcription not denies the results of experiments in which such changes were shown. What theoretic explanations of EMF-induced gene activity regulation are proposed?

In a series of works of R. Goodman and M. Blank and co-authors some mechanisms of the regulatory action of EMFs on gene activity were proposed. The activation of binding of both HSF and AP-1 to DNA is induced by magnetic fields [17]. The genes response to EMFs is regulated by with Electromagnetic Response Elements. A 900 base pair segment of the c-myc promoter, containing eight nCTCTn sequences, is required for the induction of $\mathrm{c}$-myc expression by Electromagnetic (EM) fields. Similarly, a $70 \mathrm{bp}$ region of the HSP70 promoter, containing three nCTCTn sequences, is required for the induction of HSP70 expression by EM fields. These sequences appear to act as Electromagnetic Field Response Elements (EMREs), since the ability of an EM field to induce stress proteins gradually disappears as the EMREs are mutated [18]. The EMF may interact directly with electrons in DNA and the electron transfer would result in gene expression [19]. Because of the low energy required, interaction with electrons in $\mathrm{H}$-bonds may be the initial perturbation that leads double stranded DNA to come apart and begin the complex process of transcription to messenger RNA [20]. This model is detailed in [21]. Transfer of charge in electromagnetic field could contribute to separation of base pairs in DNA. An increase in local charge can cause separation of small groups of base pairs, and the low electronegativities of CTCT bases associated with the response to EMF increase the likelihood of electron displacement. EMF initiated DNA separation can set in motion the inter-connected biochemical signaling pathways that are activated in the stress response [21].

The EMF-induced effects on calcium concentration in cell are very interesting in connection with the role of calcium as an intracellular signal messenger [98] and the regulator of gene activity [98-101]. The calcium concentration increases in cell under the action of EMFs $[102,103]$. During the chronic exposure the calcium ions are released from the membrane, which are membrane bound and are released into 
the cytosol [104]. The influence of Extremely Low Frequency (ELF) magnetic fields on the transport of $\mathrm{Ca}^{2+}$ was studied in a biological system consisting of highly purified plasma membrane vesicles. Vesicles were exposed for $30 \mathrm{~min}$ at $32^{\circ} \mathrm{C}$ and the calcium efflux was studied using radioactive ${ }^{45} \mathrm{Ca}$ as a tracer. The plasma membrane vesicles were loaded with $\mathrm{Ca}^{2+}$. After $30 \mathrm{~min}$ the vesicular $\mathrm{Ca}^{2+}$ content was decreased to approximately $50 \%$ of the initial value. Static magnetic fields ranging from 27 to $37 \mathrm{mT}$ and time varying magnetic fields with frequencies between 7 and $72 \mathrm{~Hz}$ and amplitudes between 13 and $114 \mathrm{mT}$ (peak) were used. At suitable combinations of static and time varying magnetic fields directly interact with the $\mathrm{Ca}^{2+}$ channel protein in the cell membrane, and it could be quantitatively confirm the model proposed in [105].

Calcium plays a leading role in EMF-induced cell differentiation, as it is shown in the works cited below. Exposure to $50 \mathrm{~Hz}$ EFs significantly enhanced proliferation in human neuroblastoma IMR32 (+40\%) and rat pituitary GH3 cells $(+38 \%)$. These data provide the direct evidence that EFs enhance the expression of voltage-gated $\mathrm{Ca}^{2+}$ channels on plasma membrane of the exposed cells. The consequent increase in $\mathrm{Ca}^{2+}$ influx is likely responsible for the EF-induced modulation of neuronal cell proliferation and apoptosis [106]. The differentiating neural stem/ progenitor cells were exposed to EMNs $(1 \mathrm{mT}, 50 \mathrm{~Hz})$, Cell exposure promotes neuronal differentiation of cells by upregulating $\mathrm{Ca}(\mathrm{v}) 1$ channel expression and function [107].

The recent review [108] provides support for a pathway of the biological action of ultralow frequency and microwave EMFs, nanosecond pulses and static electrical or magnetic fields via EMF activation of voltage-gated calcium channels which leads to rapid elevation of intracellular $\mathrm{Ca}^{2+}$, nitric oxide and in some cases at least, peroxynitrite. Potentially therapeutic effects may be mediated through the $\mathrm{Ca}^{2+} /$ nitric oxide/cGMP/protein kinase $\mathrm{G}$ pathway. Pathophysiological effects may be mediated through the $\mathrm{Ca}^{2+} /$ nitric oxide/peroxynitrite pathway.

In works of research group of Kharkiv National University the EMFsinduced condensation of chromatin in cell nuclei was demonstrated. Chromatin - the main component of cell nucleus in the period when cell is not dividing is presented in two forms - euchromatin (the main part of chromatin) and the heterochromatin (the condensed, nonactive chromatin). The simple method for determination of the portion of heterochromatin by counting the number of heterochromatin granules in a probe of cells and determination of average number per cell was proposed for buccal epithelium cells - cells of cheek mucosa [109]. In a series of works it was demonstrated that the low energy EMF $\left(10-100 \mu \mathrm{W} / \mathrm{cm}^{2}\right)$ and static magnetic field $(25 \mathrm{mT})$ induce chromatin condensation (heterochromatinization) [38,47,110-114]. It is supposed that this phenomenon reflects the process of regulation of genetic activity at cytological level, because heterochromatinization is connected with decrease of functional activity of chromatin $[115,116]$. The EMF-induced chromatin condensation is the necessary stage of further thin process of regulation activity of individual genes [114]. It was shown the decrease of the functional activity of polytene (giant) chromosomes in EMF-exposed Drosophila. In larvae developed from the EMF-exposed eggs at the prepupal stage 3 of 8 chromosomal puffs tested (71CE, 82EF, and 83E) had significantly smaller dimensions than these in control [117]. In our opinion, the mechanism of EMF-induced chromatin condensation may include the primary effects connected with changes in DNA-protein interactions induced by EMF, and also the known mechanisms of chromatin remodeling during chromatin condensation. The increase of the intranuclear concentration of calcium ions may be involved in the process of EMF-induced chromatin condensation.

\section{Conclusion}

The problem of primary mechanism of EMF-induced effects on the cellular level is far from its solving. It is difficult to identify the leading cause of such effects. Sometimes the effects are registered in some laboratories, but not registered in others. This phenomenon may be partly explained by differences in the EMF sources and experimental objects applied. The cells of different genotype $[118,119]$ and of the different of stage of differentiation [120] reveal different reactions to the same EMFs. So, these differences may be taken into consideration when experiments are panned and analyzed. The good established are facts of oxidative stress and gene regulation changes after EMFs action. But sometimes it is difficult to distinguish the primary cause of EMFinduced effect and the secondary consequence of EMF action. This consideration may be applied to the EMF-induced oxidation stress and to gene regulation pattern, because these events accompany the action of different unfavorable factors on cell. It is possible that such complex reaction as cell reaction on EMFs has many competing mechanisms and under different conditions to the fore is advanced one of them. In our opinion the primary reaction to electromagnetic field may be connected with the level of gene activity regulation. The reaction of chromatin condensation is one of the "safe" cell reactions to EMF which is always registered and which we can observe immediately after applying of EMF. The investigation of molecular mechanisms underlying this reaction can give new important information about the primary mechanism of EMF action on cell.

\section{References}

1. Banik S, Bandyopadhyay S, Ganguly S (2003) Bioeffects of microwave--a brief review. Bioresour Technol 87: 155-159.

2. Vorst AV, Rosen A, Kotsuka Y (2006) RF/microwave interaction with biologica tissues (Wiley Series in microwave and optical engineering). Wiley-IEEE Press, New York, USA.

3. Barnes FS, Greenebaum B (2007) Bioengineering and biophysical aspects of electromagnetic fields. Handbook of biological effects of electromagnetic fields ( $3^{\text {rd }}$ edn.), CRC Press, Boca Raton, New York, Washington, USA.

4. Furse C, Christensen DA, Durney CH (2009) Basic Introduction to bioelectromagnetics ( $2^{\text {nd }}$ edn.), CRC Press, Boca Raton, New York, Washington, USA.

5. Rosch PJ, Markov MS (2004) Bioelectromagnetic medicine. Marcel Dekker Inc New York, USA.

6. Andrä W, Nowak H (2007) Magnetism in medicine: a handbook ( $2^{\text {nd }}$ edn.) Wiley-VCH Verlag GmbH \& Co. KGaA.

7. Markov MS (2007) Magnetic field therapy: a review. Electromagn Biol Med 26 $1-23$.

8. Takahashi A, Ohnishi T (2009) Molecular mechanisms involved in adaptive responses to radiation, UV light, and heat. J Radiat Res 50: 385-393.

9. Kovacic P, Somanathan R (2010) Electromagnetic fields: mechanism, cell signaling, other bioprocesses, toxicity, radicals, antioxidants and beneficial effects. J Recept Signal Transduct Res 30: 214-226.

10. Markov MS (2014) Electromagnetic fields and life. J Electr Electron Syst 3: 119

11. Ghodbane S, Lahbib A, Sakly M, Abdelmelek H (2013) Bioeffects of static magnetic fields: oxidative stress, genotoxic effects, and cancer studies. Biomed Res Int 2013: 602987.

12. Szmigielski S (2013) Reaction of the immune system to low-level RF/MW exposures. Sci Total Environ 454-455: 393-400.

13. Desai NR, Kesari KK, Agarwal A (2009) Pathophysiology of cell phone radiation: oxidative stress and carcinogenesis with focus on male reproductive system. Reprod Biol Endocrinol 7: 114. 
Citation: Shckorbatov Y (2014) The Main Approaches of Studying the Mechanisms of Action of Artificial Electromagnetic Fields on Cell. J Electr Electron Syst 3: 123. doi:10.4172/2332-0796.1000123

14. Kesari KK, Siddiqui MH, Meena R, Verma HN, Kumar S (2013) Cell phone radiation exposure on brain and associated biological systems. Indian $\mathrm{J}$ Exp Biol 51: 187-200.

15. Bhat MA, Kumar V, Gupta GK (2013) Effects of mobile phone and mobile phone tower radiations on human health. International Journal of Recent Scientific Research 4:1422- 1426.

16. Hardell L, Carlberga M, Hansson Mild K (2013) Use of mobile phones and cordless phones is associated with increased risk for glioma and acoustic neuroma. Pathophysiology 20: 85-110.

17. Lin H, Han L, Blank M, Head M, Goodman R (1998) Magnetic field activation of protein-DNA binding. J Cell Biochemis 70: 297-303.

18. Lin H, Blank M, Rossol-Haseroth K, Goodman R (2001) Regulating genes with electromagnetic response elements. J Cell Biochemis 81: 143-148.

19. Goodman R, Blank M (2002) Insights into electromagnetic interaction mechanisms. J Cell Physiol 192: 16-22.

20. Blank M, Goodman R (2004) Initial interactions in electromagnetic field-induced biosynthesis. J Cell Physiol 199: 359-363.

21. Blank M, Goodman R (2008) A mechanism for stimulation of biosynthesis by electromagnetic fields: charge transfer in DNA and base pair separation. J Cell Physiol 214: 20-26.

22. Michaelson SM (1980) Microwave biological effects: An overview. Proceedings of the IEEE 68: 40-49.

23. World Health Organization (1981) International programme on chemical safety environmental health criteria. Radiofrequency and microwaves, Geneva.

24. Levit BB, Lai H (2010) Biological effects from exposure to electromagnetic radiation emitted by cell tower base stations and other antenna arrays. Environ Rev 18: 369-395.

25. Hocking B (2001) Microwave sickness: a reappraisal. Occup Med (Lond) 51 $66-69$.

26. Hutter H-P, Moshammer H, Wallner P, Kundi M (2006) Subjective symptoms, sleeping problems, and cognitive performance in subjects living near mobile phone base stations. Occup Environ Med 63: 307-313.

27. Yildirim M, Yildirim A, Zamani AG, Okudan N (2010) Effect of mobile phone station on micronucleus frequency and chromosomal aberrations in human blood cells. Genet Couns 21: 243-251.

28. Hardell L, Carlberg M, Hansson Mild K (2009) Epidemiological evidence for an association between use of wireless phones and tumor diseases. Pathophysiology 16: 113-122.

29. Poulsen AH, Friis S, Johansen C, Jensen A, Frei $P$, et al. (2013) Mobile phone use and the risk of skin cancer: a nationwide cohort study in Denmark. Am J Epidemiol 178: 190-197.

30. Sohrabi M-R, Tarjoman T, Abadi A, Yavari P (2010) Living near overhead high voltage transmission power lines as a risk factor for childhood acute lymphoblastic leukemia: a case-control study. Asian Pac J Cancer Prev 11 423-427.

31. Elliott P, Toledano MB, Bennett J, Beale L, de Hoogh K, et al. (2010) Mobile phone base stations and early childhood cancers: case-control study. BMJ 340: c3077.

32. García AM, Sisternas A, Hoyos SP (2008) Occupational exposure to extremely low frequency electric and magnetic fields and Alzheimer disease: a metaanalysis. Int J Epidemiol 37: 329-340.

33. Hartwig V, Giovannetti G, Vanello N, Lombardi M, Landini L, et al. (2009) Biological effects and safety in magnetic resonance imaging: A review. Int $\mathrm{J}$ Environ Res Public Health 6: 1778-1798

34. Zaremba LA (2003) Guidance for industry and FDA staff: criteria for significan risk investigations of magnetic resonance diagnostic devices. U.S. Department of Health and Human Services Food and Drug Administration. Silver Spring, MD, USA.

35. Vecchia P, Matthes R, Ziegelberger G, Lin J, Saunders R, Swerdlow A (2009) Exposure to high frequency electromagnetic fields, biological effects and health consequences $(100 \mathrm{kHz}-300 \mathrm{GHz})$. Review of the scientific evidence on dosimetry, biological effects, epidemiological observations, and health consequences concerning exposure to high frequency electromagnetic fields $(100 \mathrm{kHz}$ to $300 \mathrm{GHz})$. International Commission on Non-lonizing Radiation Protection.
36. WHO (2002) IARC Monographs on the evaluation of carcinogenic risks to humans IARC Monograph, Volume 80 . Non-lonizing radiation, Part 1: Static and Extremely Low-Frequency (ELF) electric and magnetic fields.

37. WHO Press Release (2011) IARC classifies radiofrequency electromagnetic fields as possibly carcinogenic to humans.

38. Shckorbatov $Y(2012)$ The state of chromatin as an integrative indicator of cell stress. New Developments in Chromatin Research 6: 123-144. Nova Publishers, New York, USA.

39. Fröhlich H (1968) Long-range coherence and energy storage in biological systems. Int J Quantum Chem 2: 641-649.

40. Ismailov ESh (1971) Mechanism of the effect of microwaves on the permeability of erythrocytes for potassium and sodium ions. Nauchnye Dokl Vyss Shkoly Biol Nauki 3: 58-60 (in Russian).

41. Alekseev SI, Ziskin MC (1995) Millimeter microwave effect on ion transport across lipid bilayer membranes. Bioelectromagnetics 16: 124-131.

42. Liburdy RP, Vanek PFJr (1985) Microwaves and the cell membrane: II Temperature, plasma, and oxygen mediate microwave-induced membrane permeability in the erythrocyte. Radiat Res 102: 190-205

43. Garner AL, Deminsky M, Neculaes VB, Chashihin V, Knizhnik A, et al. (2013) Cell membrane thermal gradients induced by electromagnetic fields. J App Phys 113: 214701-214701-11.

44. Golant MB (1989) Resonance effect of coherent millimeter-band electromagnetic waves on living organisms. Biofizika 34: 1004-1014 (in Russian).

45. Kataev AA, Aleksandrov AA, Tikhonova LL, Berestovskii GN (1993) Frequencydependent effect of millimeter electromagnetic waves on ionic currents algae Nitellopsis. Non-thermal effects. Biofizika 38: 446-462 (in Russian).

46. Shckorbatov YG, Shakhbazov VG, Navrotskaya VV, Grabina VA, Sirenko SP, et al. (2002) Electrokinetic properties of nuclei and membrane permeability in human buccal epithelium cells influenced by the low-level microwave radiation. Electrophoresis 23: 2074-2079.

47. Shckorbatov YG, Pasiuga VN, Kolchigin NN, Grabina VA, Ivanchenko DD, et al. (2011) Cell nucleus and membrane recovery after exposure to microwaves. Proceedings of the Latvian Academy of Sciences 65: 13-20.

48. Ikehara T, Yamaguchi H, Hosokawa K, Miyamoto H, Aizawa K (2003) Effects of ELF magnetic field on membrane protein structure of living HeLa cells studied by Fourier transform infrared spectroscopy. Bioelectromagnetics 24: 457-464.

49. Gaber MH, Abd El Halim N, Khalil WA (2005) Effect of microwave radiation on the biophysical properties of liposomes. Bioelectromagnetics 26: 194-200.

50. Halgamuge MN, Perssont BRR, Salford LG, Mendis P, Eberhardt J (2009) Comparison between two models for interactions between electric and magnetic fields and proteins in cell membranes. Environ Eng Sci 26: 1473-1480.

51. Hill E, Ritz T (2010) Can disordered radical pair systems provide a basis for a magnetic compass in animals? J R Soc Interface 7: S265-S271.

52. Rodgers CT, Hore PJ (2009) Chemical magnetoreception in birds: The radical pair mechanism. Proc Natl Acad Sci USA 106: 353-360.

53. Consales C, Merla C, Marino C, Benassi B (2012) Electromagnetic fields, oxidative stress, and neurodegeneration. International Journal of Cell Biology 2012: 16 pages.

54. Ilhan A, Gurel A, Armutcu F, Kamisli S, Iraz M, et al. (2004) Ginkgo biloba prevents mobile phone-induced oxidative stress in rat brain. Clin Chim Acta 340: 153-162.

55. Elhag MA, Nabil GM, Attia AM (2007) Effects of electromagnetic field produced by mobile phones on the oxidant and antioxidant status of rats. Pak J Biol Sci 10: $4271-4274$

56. Meral I, Mert H, Mert N, Deger Y, Yoruk I, et al. (2007) Effects of 900-MHz electromagnetic field emitted from cellular phone on brain oxidative stress and some vitamin levels of guinea pigs. Brain Res 1169: 120-124.

57. Balci M, Namuslu M, Devrim E, Durak I (2009) Effects of computer monitoremitted radiation on oxidant/antioxidant balance in cornea and lens from rats. Mol Vis 15: 2521-2525.

58. Yao-Sheng Lu, Bao-Tian Huang, Yao-Xiong Huang (2012) Reactive oxygen species formation and apoptosis in human peripheral blood mononuclear cell induced by $900 \mathrm{MHz}$ mobile phone radiation. Oxidative Medicine and Cellula Longevity 2012: 8 pages. 
Citation: Shckorbatov Y (2014) The Main Approaches of Studying the Mechanisms of Action of Artificial Electromagnetic Fields on Cell. J Electr Electron Syst 3: 123. doi:10.4172/2332-0796.1000123

Page 7 of 8

59. Achudume AC, Onibere B, Aina F (2009) Bioeffects of electromagnetic base station on glutathione reductase, lipid peroxidation and total cholesterol in different tissues. Biology and Medicine 1: 33-38.

60. Xu S, Zhou Z, Zhang L, Yu Z, Zhang W, et al. (2010) Exposure to $1800 \mathrm{MHz}$ radiofrequency radiation induces oxidative damage to mitochondrial DNA in primary cultured neurons. Brain Res 1311: 189-196.

61. Kesari KK, Kumar S, Behari J (2011) Effects of radiofrequency electromagnetic wave exposure from cellular phones on the reproductive pattern in male Wistar rats. Appl Biochem Biotechnol 164: 546-559.

62. Megha K, Deshmukh PS, Banerjee BD, Tripathi AK, Abegaonkar MP (2012) Microwave radiation induced oxidative stress, cognitive impairment and inflammation in brain of Fischer rats. Indian J Exp Biol 50: 889-896.

63. Deshmukh PS, Banerjee BD, Abegaonkar MP, Megha K, Ahmed RS, et al. (2013) Effect of low level microwave radiation exposure on cognitive function and oxidative stress in rats. Indian J Biochem Biophys 50: 114-119.

64. Avci B, Akar A, Bilgici B, Tunçel ÖK (2012) Oxidative stress induced by $1.8 \mathrm{GHz}$ radio frequency electromagnetic radiation and effects of garlic extract in rats. Int J Radiat Biol 88: 799-805.

65. Goraca A, Ciejka E, Piechota A (2010) Effects of extremely low frequency magnetic field on the parameters of oxidative stress in heart. $J$ Physio Pharmacol 61: 333-338.

66. Ciejka E, Kleniewska P, Skibska B, Goraca A (2011) Effects of extremely low frequency magnetic field on oxidative balance in brain of rats. J Physio Pharmacol 62: 657-661.

67. Chu LY, Lee JH, Nam YS, Lee YJ, Park WH, et al. (2011) Extremely low frequency magnetic field induces oxidative stress in mouse cerebellum. Gen Physiol Biophys 30: 415-521.

68. Selaković V, Rauš Balind S, Radenović L, Prolić Z, Janać B (2013) Agedependent effects of ELF-MF on oxidative stress in the brain of Mongolian gerbils. Cell Biochem Biophys 66: 513-521.

69. Hong MN, Han NK, Lee HC, Ko YK, Chi SG, et al. (2012) Extremely low frequency magnetic fields do not elicit oxidative stress in MCF10A cells. J Radiat Res 53: 79-86.

70. Glinka M, Sieroń A, Birkner E, Cieślar G (2013) Influence of extremely lowfrequency magnetic field on the activity of antioxidant enzymes during skin wound healing in rats. Electromagn Biol Med 32: 463-470

71. Avery SV (2011) Molecular targets of oxidative stress. Biochem J 434: 201-210.

72. De luliis GN, Newey RJ, King BV, Aitken RJ (2009) Mobile phone radiation induces reactive oxygen species production and DNA damage in human spermatozoa in vitro. PLoS One 4: e6446.

73. Zotti-Martelli L, Peccatori M, Maggini V, Ballardin M, Barale R (2005) Individual responsiveness to induction of micronuclei in human lymphocytes after exposure in vitro to 1800-MHz microwave radiation. Mutat Res 582: 42-52.

74. Karaca E, Durmaz B, Aktug H, Yildiz T, Guducu C, et al. (2012) The genotoxic effect of radiofrequency waves on mouse brain. J Neurooncol 106: 53-58.

75. Atlı Şekeroğlu Z, Akar A, Şekeroğlu V (2013) Evaluation of the cytogenotoxic damage in immature and mature rats exposed to $900 \mathrm{MHz}$ radiofrequency electromagnetic fields. Int J Radiat Biol 89: 985-992.

76. Paulraj R, Behari J (2006) Single strand DNA breaks in rat brain cells exposed to microwave radiation. Mutat Res 596: 76-80

77. Deshmukh PS, Megha K, Banerjee BD, Ahmed RS, Chandna S, et al. (2013) Detection of low level microwave radiation induced deoxyribonucleic acid damage vis-à-vis genotoxicity in brain of Fischer rats. Toxicol Int 20: 19-24.

78. Mihai CT, Rotinberg P, Brinza F, Vochita G (2014) Extremely low-frequency electromagnetic fields cause DNA strand breaks in normal cells. J Environ Health Sci Eng 12: 15

79. Czyz J, Guan K, Zeng Q, Nikolova T, Meister A, et al. (2004) High frequency electromagnetic fields (GSM signals) affect gene expression levels in tumor suppressor p53-deficient embryonic stem cells. Bioelectromagnetics 25: 296 307.

80. Nikolova T, Czyz J, Rolletschek A, Blyszczuk P, Fuchs J, et al. (2005) Electromagnetic fields affect transcript levels of apoptosis-related genes in embryonic stem cell-derived neural. FASEB J 19: 1686-1688.
81. ZhaoT-Y, Shi-Ping Zou S-P, Knapp PE (2007) Exposure to cell phone radiation up-regulates apoptosis genes in primary cultures of neurons and astrocytes. Neurosci Lett 412: 34-38.

82. Vian A, Roux D, Girard S, Bonnet P, Paladian F, et al. (2006) Microwave irradiation affects gene expression in plants. Plant Signal Behav 1: 67-70.

83. Gerner C, Haudek V, SchandI U, Bayer E, Gundacker N, et al. (2010) Increased protein synthesis by cells exposed to a $1,800-\mathrm{MHz}$ radio-frequency mobile phone electromagnetic field, detected by proteome profiling. Int Arch Occup Environ Health 83: 691-702.

84. Li HW, Yao K, Jin HY, Sun LX, Lu DQ, et al. (2007) Proteomic analysis of human lens epithelial cells exposed to microwaves. Jpn J Ophthalmol 51: 412-416.

85. Tsai MT, Li WJ, Tuan RS, Chang WH (2009) Modulation of osteogenesis in human mesenchymal stem cells by specific pulsed electromagnetic field stimulation. J Orthop Res 27: 1169-1174.

86. Hinsenkamp M, Collard JF (2011) Bone Morphogenic Protein--mRNA upregulation after exposure to low frequency electric field. Int Orthop 35: 15771581.

87. Kabacik S, Kirschenlohr H, Raffy C, Whitehill K, Coster M, et al. (2013) Investigation of transcriptional responses of juvenile mouse bone marrow to power frequency magnetic fields. Mutat Res 745-746: 40-45.

88. Morehouse CA, Owen RD (2000) Exposure of Daudi cells to low-frequency magnetic fields does not elevate MYC steady-state mRNA levels. Radiat Res 153: 663-669.

89. Yomori H, Yasunaga K, Takahashi C, Tanaka A, Takashima S, et al. (2002) Elliptically polarized magnetic fields do not alter immediate early response genes expression levels in human glioblastoma cells. Bioelectromagnetics 23 89-96.

90. Shi B, Farboud B, Nuccitelli R, Isseroff RR (2003) Power-line frequency electromagnetic fields do not induce changes in phosphorylation, localization, or expression of the 27-Kilodalton heat shock protein in human keratinocytes. Environ Health Perspect 111: 281-288.

91. Coulton LA, Harris PA, Barker AT, Pockley, AG (2004) Effect of $50 \mathrm{~Hz}$ electromagnetic fFields on the induction of heat-shock protein gene expression in human leukocytes. Radiat Res 161: 430-434.

92. Thorlin T, Rouquette JM, Hamnerius Y, Hansson E, Persson M, et al. (2006) Exposure of cultured astroglial and microglial brain cells to $900 \mathrm{MHz}$ microwave radiation. Radiat Res 166: 409-421.

93. Chauhan V, Mariampillai A, Bellier PV, Qutob SS, Gajda GB, et al. (2006) Gene expression analysis of a human lymphoblastoma cell line exposed in vitro to an intermittent $1.9 \mathrm{GHz}$ pulse-modulated radiofrequency field. Radiat Res 165 424-429.

94. Nylund R, Kuster N, Leszczynski D (2010) Analysis of proteome response to the mobile phone radiation in two types of human primary endothelial cells Proteome Science 8: 52

95. Kim KB, Byun HO, Han NK, Ko YG, Choi HD, et al. (2010) Two-dimensiona electrophoretic analysis of radio frequency radiation-exposed MCF7 breast cancer cells. J Radiat Res 51: 205-213.

96. Sakurai T, KiyokoewaT, Eijiro Narita E, Suzyki Y, Taki M, et al. (2011) Analysis of gene expression in a human-derived glial cell line exposed to $2.45 \mathrm{GHz}$ continuous radiofrequency electromagnetic fields. J Radiat Res 52: 185-192.

97. Vanderstraeten J, Verschaeve L (2008) Gene and protein expression following exposure to radiofrequency fields from mobile phones. Environ Health Perspect 116: 1131-1135.

98. Cerella C, Diederich M, Ghibelli L (2010) The Dual Role of Calcium as Messenger and Stressor in Cell Damage, Death, and Survival. Int J Cell Bio 2010: 546163 .

99. Hardingham GE, Bading H (1998) Nuclear calcium: a key regulator of gene expression. Biometals 11: 345-358.

100. Alonso MT, García-Sancho J (2011) Nuclear $\mathrm{Ca}^{2+}$ signaling. Cell Calcium 49 280-289.

101. Bengtson CP, Bading H (2012) Nuclear Calcium Signaling. Synaptic Plasticity, Advances in Experimental Medicine and Biology, Springer-Verlag, Wien, NY USA. 
Citation: Shckorbatov Y (2014) The Main Approaches of Studying the Mechanisms of Action of Artificial Electromagnetic Fields on Cell. J Electr Electron Syst 3: 123. doi:10.4172/2332-0796.1000123

Page 8 of 8

102. Cho MR, Thatte HS, Silvia MT, Golan DE (1999) Transmembrane calcium influx induced by ac electric fields. FASEB J 13: 677-683.

103. Pazur A, Rassadina $\vee(2009)$ Transient effect of weak electromagnetic fields on calcium ion concentration in Arabidopsis thaliana. BMC Plant Biology 9:47.

104. Paulraj R, Behari J (2012) Biochemical Changes in Rat Brain Exposed to Low Intensity 9.9 GHz Microwave Radiation. Cell Biochem Biophys 63: 97-102.

105. Bauréus Koch CLM, Sommarin M, Persson BRR, Salford LG, Eberhardt JL (2003) Interaction between weak low frequency magnetic fields and cell membranes. Bioelectromagnetics 24: 395-402.

106. Grassi C, D'Ascenzo M, Torsello A, Martinotti G, Wolf F, et al. (2004) Effects of $50 \mathrm{~Hz}$ electromagnetic fields on voltage-gated $\mathrm{Ca}^{2+}$ channels and their role in modulation of neuroendocrine cell proliferation and death. Cell Calcium 35: 307-315.

107.Piacentini R, Ripoli C, Mezzogori D, Azzena GB, Grassi C (2008) Extremely low-frequency electromagnetic fields promote in vitro neurogenesis via upregulation of $\mathrm{Ca}(\mathrm{v})$ 1-channel activity. J Cell Physiol 215: 129-139.

108.Pall ML (2013) Electromagnetic fields act via activation of voltage-gated calcium channels to produce beneficial or adverse effects. J Cell Mol Med 17: 958-965.

109. Shckorbatov YG (1999) He-Ne laser light induced changes in the state of the chromatin in human cells. Naturwissenschaften 86: 452-453.

110. Shckorbatov YG, Pasiuga VN, Kolchigin NN, Batrakov DO, Kazansky OV, et al. (2009) Changes in the human nuclear chromatin induced by ultra wideband pulse irradiation. Central European Journal of Biology 4: 97-106.

111. Shckorbatov YG, Pasiuga VN, Kolchigin NN, Grabina VA, Batrakov DO, et al. (2009) The influence of differently polarized microwave radiation on chromatin in human cells. Int J Radiat Biol 85: 322-329.
112. Shckorbatov YG, Pasiuga VN, Goncharuk EI, Petrenko TPh, Grabina VA et al. (2010) Effects of differently polarized microwave radiation on the microscopic structure of the nuclei in human fibroblasts. J Zhejiang Univ Sci B 11: 801-805.

113. Shckorbatov YG, Rudneva II, Pasiuga VN. Grabina VA, Kolchigin NN, et al (2010) Electromagnetic fields effects on Artemia hatching and chromatin state. Central European Journal of Biology 5: 785-790.

114. Shckorbatov YG, Katrich VA, Pasiuga VN, Rudenko AO (2013) Cell Response to Electromagnetic Field: Nuclear and Membrane Mechanisms. Nova Biomedical, New York, USA.

115. Martin RM, Cardoso MC (2010) Chromatin condensation modulates access and binding of nuclear proteins. FASEB J 24: 1066-1072.

116. Biran A, Meshorer E (2012) Concise review: chromatin and genome organization in reprogramming. Stem Cells 30: 1793-1799.

117. Shakina LA Pasiuga VN, Dumin OM, Shckorbatov YG (2011) Effects of microwaves on the puffing pattern of $D$. melanogaster. Central European Journal of Biology 6: 524-530.

118. Tenuzzo B, Chionna A, Panzarini E, Lanubile R Tarantino P, et al. (2006) Biological effects of $6 \mathrm{mT}$ static magnetic fields: a comparative study in different cell types. Bioelectromagnetics 7: 560-577.

119. Ding G-R, Yaguchi H, Yoshida M, Miyakoshi J (2000) Increase in X-Rayinduced mutations by exposure to magnetic field $(60 \mathrm{~Hz}, 5 \mathrm{mT})$ in NF-kBinhibited cells. Biochem Bioph Res Co 276: 238-243.

120. Tsai MT, Li WJ, Tuan RS, Chang WH (2009) Modulation of osteogenesis in human mesenchymal stem cells by specific pulsed electromagnetic field stimulation. J Orthop Res 27: 1169-1174. 